\title{
Desulfurization Performance of Rare Earth Mono-substituted Heteropoly Compounds
}

\author{
Xiaoning Pei ${ }^{1,2}$, Rui Wang ${ }^{*}$ \\ ${ }^{1}$ Shenzhen Research Institute of Shandong University, Shenzhen, Guangdong 518057, China \\ ${ }^{2}$ School of Environmental Science and Engineering, Shandong University, Qingdao, Shandong 266237, China
}

\begin{abstract}
In this study, a series of rare earth monosubstituted Dawson-type polyoxometalates were synthesized for highly effective removal of hydrogen sulfide $\left(\mathrm{H}_{2} \mathrm{~S}\right)$. The unused, used and regenerated polyoxometalates were characterized by Fourier transform infrared spectroscopy (FT-IR) and X-ray photoelectron spectroscopy (XPS). The results confirmed that $\mathrm{K}_{17}\left[\operatorname{Pr}\left(\mathrm{P}_{2} \mathrm{Mo}_{17} \mathrm{O}_{61}\right)_{2}\right]$ could maintain a complete Dawson-type structure even after absorption and regeneration. $\mathrm{H}_{2} \mathrm{~S}$ absorption study showed that $\mathrm{K}_{17}\left[\operatorname{Pr}\left(\mathrm{P}_{2} \mathrm{Mo}_{17} \mathrm{O}_{61}\right)_{2}\right]$ had the remarkable desulfurization and regeneration capabilities. Optimization experiments showed that $\mathrm{K}_{17}\left[\operatorname{Pr}\left(\mathrm{P}_{2} \mathrm{Mo}_{17} \mathrm{O}_{61}\right)_{2}\right]$ under the condition of low $\mathrm{H}_{2} \mathrm{~S}$ concentration or high dosage of $\mathrm{K}_{17}\left[\operatorname{Pr}\left(\mathrm{P}_{2} \mathrm{Mo}_{17} \mathrm{O}_{61}\right)_{2}\right]$ had the ideal desulfurization performance. An appropriate temperature of $25^{\circ} \mathrm{C}$ is necessary for high removal efficiency. The optimum $\mathrm{pH}$ value for desulfurization is 6.8. The desulfurization product was proved to be $\mathrm{SO}_{4}{ }^{2-}$.
\end{abstract}

Keywords: Rare earth ion; Heteropoly compounds; $\mathrm{H}_{2} \mathrm{~S}$; Desulfurization.

\section{INTRODUCTION}

Hydrogen sulfide $\left(\mathrm{H}_{2} \mathrm{~S}\right)$ is a common pollutant in oil and gas production/processing, wastewater treatment plants, fossil fuel combustion, and landfill gases (Ko et al., 2015; Bamdad et al., 2018; Widiana et al., 2019). The removal of $\mathrm{H}_{2} \mathrm{~S}$ from these industrial gases is very necessary owing to its highly toxic, odorous and corrosive natures (Pan et al., 2015; Beidari et al., 2017). It can be oxidized to $\mathrm{SO}_{2}$, which is one of the major sources of acid rain (Chen et al., 2017; Cheng et al., 2019). In addition, $\mathrm{H}_{2} \mathrm{~S}$ can cause severe health problems for human being, affect the catalytic activity of industrial catalysts, and corrode device as well as oil-gas pipe line (Yang et al., 2006; Jiang et al., 2016; Chandran et al., 2018; Wang et al., 2019).

Nowadays, a number of methods are used for removing $\mathrm{H}_{2} \mathrm{~S}$ (Widiana et al., 2017; Habeeb et al., 2018; Liu et al., 2018; Huang et al., 2019a). Desulfurization processes can be generally divided into two methods, i.e., dry and wet methods. Dry method of desulfurization is carried out by using a solid adsorbent such as activated carbons (Xie et al., 2017; Liu et al., 2019), metal oxides, molecular sieves or metal elements (Zhang et al., 2017; Cheng et al., 2018). This method is simple and easy to operate, but the adsorbents have the disadvantages of poor regenerability and high

\footnotetext{
* Corresponding author.

E-mail address: wangrui@sdu.edu.cn
}

running cost (Ozekmekci et al., 2015; Tian et al., 2017; Lee et al., 2019). Whereas, the wet methods, especially those utilizing aqueous solution for catalytic and oxidative desulfurization, normally possess high removal efficiency for $\mathrm{H}_{2} \mathrm{~S}$ at lower cost (Zhai et al., 2012; Liu et al., 2017a; Zhang et al., 2018). Due to its stable structure and good redox properties, heteropoly acid is an excellent catalyst for oxidative desulfurization (Ou et al., 2001; Wang et al., 2012; Choi et al., 2014; Liu et al., 2017).

Heteropoly anions, as an oxyanions, have several structures, including Keggin, Dawson, Anderson, Waugh and Silverton types. (Timofeeva et al., 2003; Ko et al., 2012). Among them, two well-know structures are Keggin-type and Dawsontype. These heteropoly compounds (HPCs) with stable structures have excellent redox properties and remarkable homogeneous and heterogeneous catalytic activity for the selective oxidation and acid catalysis reactions (Huang et $a l ., 2019 b)$. These two types of HPCs are often used for the oxidative dehydrogenation. To the best of our knowledge, however, there are still many restrictions on desulfurization applications of HPCs (Kozhevnikov et al., 1982; Li et al., 2007). Peacock and Weakley (1997a, b) firstly reported the single-defect 2:17 series of Dawson-type HPCs with the single-substituted metal ion having large radius. Haraguchi et al. (1994) found that the size of the heteroatoms affects the occlusion angle of the unsaturated entities of the anion. They reported that the heteropolytungstate anion with a large occlusal angle could form a stable complex with tetravalent cerium. The negative charge of the Dawson structurederived anion is greater than the Keggin structure-derived 
anion for the same heteroatom. Therefore, the tetravalent state of cerium in $\left[\mathrm{CeL}_{2}\right]^{(2 \mathrm{~m}-3)-}$ is more stable than that in $[\mathrm{CeL}]^{(\mathrm{m}-3)-}$. The cerium (III) or cerium (IV) in $\left[\mathrm{CeL}_{2}\right]^{(2 \mathrm{~m}-3)}$ - can form a sandwich structure between two respective forms, i.e., a 8-fold coordination geometry and square oxygen atom (Haraguchi et al., 1994; Jiang et al., 2018). The above results illustrated that the HPCs with Dawson structure had the better stability and redox performance than those with Keggin structure. Luo et al. (2001) showed that $\mathrm{Ln}$ ions in $\left[\mathrm{Ln}\left(\alpha-\mathrm{P}_{2} \mathrm{~W}_{17} \mathrm{O}_{61}\right)_{2}\right]^{17-}$ were trivalent and eight-coordinated, indicating that rare earth ions doped heteropoly acids had excellent redox properties. Yoshida et al. (2008) reported that heteropoly anions were stable in aqueous solution.

Herein, we synthesized a series of rare earth ion monosubstituted 2:17 double series Dawson vacancy HPCs, which were used to remove $\mathrm{H}_{2} \mathrm{~S}$ dynamically in aqueous solution for the first time. The synthesized HPCs were characterized by Fourier transform infrared (FT-IR) spectrum and X-ray photoelectron spectroscopy (XPS) to analyze their structures and compositions. The effects of various relevant factors on the desulfurization performance of HPCs were investigated by the dynamic absorption experiments.

\section{EXPERIMENTAL}

\section{Materials and Reagents}

Sodium molybdate $\left(\mathrm{Na}_{2} \mathrm{MoO}_{4} \cdot 2 \mathrm{H}_{2} \mathrm{O}\right.$, Shanghai Yindian Chemical Co., Ltd., China), phosphoric acid $\left(\mathrm{H}_{3} \mathrm{PO}_{4}, 85 \%\right.$, Tianjin Fuyu Fine Chemical Co., Ltd., China), hydrochloric acid $(\mathrm{HCl}, 36 \%)$, sulfuric acid $\left(\mathrm{H}_{2} \mathrm{SO}_{4}, 98 \%\right)$, diethyl ether $\left(\mathrm{C}_{4} \mathrm{H}_{10} \mathrm{O}, 99.5 \%\right)$ ammonium chloride $\left(\mathrm{NH}_{4} \mathrm{Cl}\right)$, praseodymium nitrate $\left(\mathrm{Pr}\left(\mathrm{NO}_{3}\right)_{3} \cdot 6 \mathrm{H}_{2} \mathrm{O}\right)$, cerous nitrate $\left(\mathrm{Ce}\left(\mathrm{NO}_{3}\right)_{3} \cdot 6 \mathrm{H}_{2} \mathrm{O}\right)$, europium nitrate $\left(\mathrm{Eu}\left(\mathrm{NO}_{3}\right)_{3} \cdot 6 \mathrm{H} 2 \mathrm{O}\right)$, sodium acetate $(\mathrm{NaAc})$, potassium chloride $(\mathrm{KCl})$, barium chloride $\left(\mathrm{BaCl}_{2} \cdot 2 \mathrm{H}_{2} \mathrm{O}\right)$. All the reagents are of analytical grade and were used as received.

\section{Methods}

Preparation of LnPMo $\left(\mathrm{Ln}=\mathrm{Pr}^{3+}, \mathrm{Gd}^{3+}, \mathrm{Sm}^{3+}\right.$, and $\left.\mathrm{Eu}^{3+}\right)$

A series of Dawson-type HPCs $\left(\mathrm{K}_{17}\left[\mathrm{Pr}\left(\mathrm{P}_{2} \mathrm{Mo}_{17} \mathrm{O}_{61}\right)_{2}\right]\right.$, $\mathrm{K}_{17}\left[\mathrm{Gd}\left(\mathrm{P}_{2} \mathrm{Mo}_{17} \mathrm{O}_{61}\right)_{2}\right], \quad \mathrm{K}_{17}\left[\mathrm{Sm}\left(\mathrm{P}_{2} \mathrm{Mo}_{17} \mathrm{O}_{61}\right)_{2}\right], \quad$ and $\left.\mathrm{K}_{17}\left[\mathrm{Eu}\left(\mathrm{P}_{2} \mathrm{Mo}_{17} \mathrm{O}_{61}\right)_{2}\right]\right)$ were synthesized. For example, the preparation process of $\mathrm{K}_{17}\left[\operatorname{Pr}\left(\mathrm{P}_{2} \mathrm{Mo}_{17} \mathrm{O}_{61}\right)_{2}\right]$ (PrPMo) is as follows (Niu et al., 2004; Wang et al., 2006): $\mathrm{Na}_{2} \mathrm{MoO}_{4} \cdot 2 \mathrm{H}_{2} \mathrm{O}$ $(100 \mathrm{~g})$ was dissolved in $450 \mathrm{~mL}$ deionized water (DW), followed by the addition of $15 \mathrm{~mL} \mathrm{H}_{3} \mathrm{PO}_{4}(85 \%)$ and $80 \mathrm{~mL}$ $\mathrm{HCl}(36 \%)$. The mixture was refluxed at $95^{\circ} \mathrm{C}$ for $8 \mathrm{~h}$ and followed by cooling at room temperature. Afterwards, $\mathrm{NH}_{4} \mathrm{Cl}(100 \mathrm{~g})$ was added into the mixture to get the precipitate. The obtained precipitate was dissolved in water along with adding concentrated $\mathrm{HCl}$ and diethyl ether. The ether was removed by adding a small amount of water into etherate. A solution of $\operatorname{Pr}\left(\mathrm{NO}_{3}\right)_{3}$ with a stoichiometric ratio of 1.5 to 2.0 was added into the above mixture. The above mixture was mixed with $50 \%$ NaAc solution with strong stirring for $2 \mathrm{~h}$, and the $\mathrm{pH}$ of the solution was adjusted to 4 . Then, $\mathrm{KCl}(25 \mathrm{~g})$ was added into the solution. The solution was cooled to room temperature in an ice bath, and the resulting solution was filtered and precipitated. The resulting precipitated solution with a $\mathrm{pH}$ value of 3.7 was recrystallized for 3 times, and the desired product was obtained after vacuum drying process.

\section{Regeneration of LnPMo via an Electrolytic Cell}

Electrochemical regeneration experiment was carried out in a H-type electrolyser. The device is made up of cathode and anode cells, which are separated by a Proton Exchange Membrane with an effective cross-sectional area of $2.3 \mathrm{~cm}^{2}$ (PEM, Nafion117, DuPont Co., Ltd., USA). Before the experiment, the PEM was activated by soaking the PEM in $\mathrm{H}_{2} \mathrm{O}_{2}$ solution (mass fraction of $5 \%$ ) at $80^{\circ} \mathrm{C}$ for $1 \mathrm{~h}$. After that, the PEM was rinsed with DW. The cathode and anode electrodes were made of $2 \mathrm{~cm} \times 5 \mathrm{~cm}$ carbon paper (TGPH-060, TORAY Co., Ltd., Japan). The power supply for the electrocatalytic cell was provided by a DC power supplied unit (IP305DE, LeDa Co., Ltd., China).

The anodic solution was obtained by transferring the absorption solution (at $\mathrm{pH}=1$ ) from the anode chamber. Then, cyclic voltammograms curve showed the strong redox peak, which proved the conducting nature and electrochemical regeneration property of the heteropoly compounds. The cathode solution was obtained by transferring $100 \mathrm{~mL}$ of $\mathrm{NaCl}(200 \mathrm{mM})$ solution into the cathode chamber. The electrochemical regeneration of the materials was initiated once the DC power supply was connected to form a closed circuit in the electrochemical cell. $\mathrm{H}_{2}$ was detected on the surface of cathode by the portable $\mathrm{H}_{2}$ detector (HT-4, hongchangxin Co., Ltd., China).

\section{Characterization}

Analytical Methods

The quantitates and qualitative properties of the synthesized compound were characterized by FT-IR spectroscopy (BRUKER Corp., Germany) in the range of 400 to $4000 \mathrm{~cm}^{-1}$. While the elemental composition of composite materials were investigated by XPS (Thermo Fisher Scientific Corp., USA).

\section{$\mathrm{H}_{2} \mathrm{~S}$ Absorption Experiments}

The $\mathrm{H}_{2} \mathrm{~S}$ absorption experiment was carried out in a cylindrical glass reactor at atmospheric pressure. The reactor has a internal diameter of $28 \mathrm{~mm}$ and height of $250 \mathrm{~mm}$. The desulfurization reagent was obtained by dissolving $0.02 \mathrm{~mol}$ LnPMo in $50 \mathrm{~mL} \mathrm{DW}$. The effects of different operating parameters on desulfurization were investigated by controlled experiments, under LnPMo concentration range of 0.0005 to $0.0015 \mathrm{~mol} \mathrm{~L}^{-1}$ and $\mathrm{pH}$ range of 1 to 9 . The mixture of $\mathrm{N}_{2}$ and $\mathrm{H}_{2} \mathrm{~S}$ with flow rate of $100 \mathrm{~mL} \mathrm{~min}^{-1}$ was introduced into the glass reactor. The residual $\mathrm{H}_{2} \mathrm{~S}$ gas was absorbed by $\mathrm{NaOH}$ solution. The $\mathrm{H}_{2} \mathrm{~S}$ concentration was detected by a TH-990s $\mathrm{H}_{2} \mathrm{~S}$ gas analyzer (Liu et al., 2017c). The desulfurization performance of LnPMo solutions was mainly evaluated by $\mathrm{H}_{2} \mathrm{~S}$ removal efficiency $(\eta, \%)$ :

$\eta=\frac{C_{0}-C_{t}}{C_{0}} \times 100 \%$ 
where $\mathrm{C}_{0}$ and $\mathrm{C}_{\mathrm{t}}$ represent the inlet and outlet concentrations of $\mathrm{H}_{2} \mathrm{~S}$, respectively.

\section{RESULTS AND DISCUSSION}

\section{FT-IR Spectrum of LnPMo}

Optical characterizations of the compounds were performed by the FT-IR spectroscopy. According to the previous studies, the FT-IR spectrum of heteropolymolybdates have distinctive differences between structures and their complexes with Ln (III) moieties: 900-700 cm $\mathrm{cm}^{-1}$ (Mo-O-Mo bending), 1000 $900 \mathrm{~cm}^{-1}$ (Mo-O stretching), and $1100-1000 \mathrm{~cm}^{-1}$ (P-O stretching), corresponding to the metal-oxygen oscillations (Lütkehoff et al., 1995; Wang et al., 2006). The FT-IR spectrum of the PrPMo (Fig. 1) shows the five characteristic vibration peaks corresponding to their specific regions such as $780 \mathrm{~cm}^{-1}$ and $874 \mathrm{~cm}^{-1}$ (Mo-O-Mo bending), $935 \mathrm{~cm}^{-1}$ (Mo-O stretch), $1034 \mathrm{~cm}^{-1}$ and $1066 \mathrm{~cm}^{-1}$ (P-O stretch). These characteristic peaks suggested that PrPMo with Dawson structure was successful synthesized (Lütkehoff et al., 1995). The characteristic vibration peaks of the complex were similar to that of standard heteropolymolybdate. The transfer of the praseodymium redox potential (III) is mainly due to the negative charge of the unsaturated heteropolymolybdate (Haraguchi et al., 1994).

\section{Effect of Lanthanide (III) Species on $\mathrm{H}_{2} \mathrm{~S}$ Removal}

The effects of different lanthanide (III) species on $\mathrm{H}_{2} \mathrm{~S}$ removal were investigated, and the results are shown in Fig. 2. The comprehensive ranking for the $\mathrm{H}_{2} \mathrm{~S}$ removal efficiency is $\mathrm{PrPMo}>$ EuPMo $>$ SmPMo $>$ GdPMo. The aqueous solution of PrPMo showed the best desulfurization and regeneration performance. According to the previous studies, the properties of heteropoly compounds are stable at ambient temperature (Liu et al., 2017b). As shown in Fig. 3, the color of the desulfurization reagent changes from light green to dark blue, then to pale green again, suggesting that PrPMo could be effectively regenerated. Therefore, PrPMo was selected as the desulfurizer in this study.

\section{Effect of Temperature on $\mathrm{H}_{2} \mathrm{~S}$ Removal}

The effect of temperature on $\mathrm{H}_{2} \mathrm{~S}$ removal was studied to optimize the performance of the heteropoly compound in the range of 25 to $75^{\circ} \mathrm{C}$ (Fig. 4). It can be found that the desulfurization efficiency decreased significantly with the temperature increase. The desulfurizer at $25^{\circ} \mathrm{C}$ had $90 \%$ desulfurization efficiency within $200 \mathrm{~min}$, and had the best removal performance. This study also showed that higher temperature was not beneficial for $\mathrm{H}_{2} \mathrm{~S}$ removal. The effect of temperature lies in two aspects: on one hand, increasing temperature tends to accelerate the chemical reaction speed; on the other hand, the solubility of $\mathrm{H}_{2} \mathrm{~S}$ in the aqueous solution tends to decline considerably at the same time. Besides, the oxidation of $\mathrm{H}_{2} \mathrm{~S}$ is exothermic, in this regard, high temperature is also not beneficial for the desulfurization process (Huang et al., 2017). Apparently, the observed results indicated that the effect of solubility plays a predominant role in the process.

\section{Effect of PrPMo Concentration on $\mathrm{H}_{2} \mathrm{~S}$ Removal}

Fig. 5 shows the effect of concentrations of PrPMo on desulfurization performance at $25^{\circ} \mathrm{C}$. At the concentration of $0.015 \mathrm{~mol} \mathrm{~L}^{-1}$ for the PrPMo, the $\mathrm{H}_{2} \mathrm{~S}$ removal efficiency achieved $90 \%$ within $250 \mathrm{~min}$. When the concentrations were $0.001 \mathrm{~mol} \mathrm{~L}^{-1}$ and $0.0005 \mathrm{~mol} \mathrm{~L}^{-1}$, either the desulfurization efficiency maintained above $90 \%$, but the time span reduced to $230 \mathrm{~min}$ and $150 \mathrm{~min}$, respectively. This revealed that higher concentration of PrPMo could achieve higher $\mathrm{H}_{2} \mathrm{~S}$ removal efficiency. The desulfurization rate decreased significantly, which was due to the depletion of

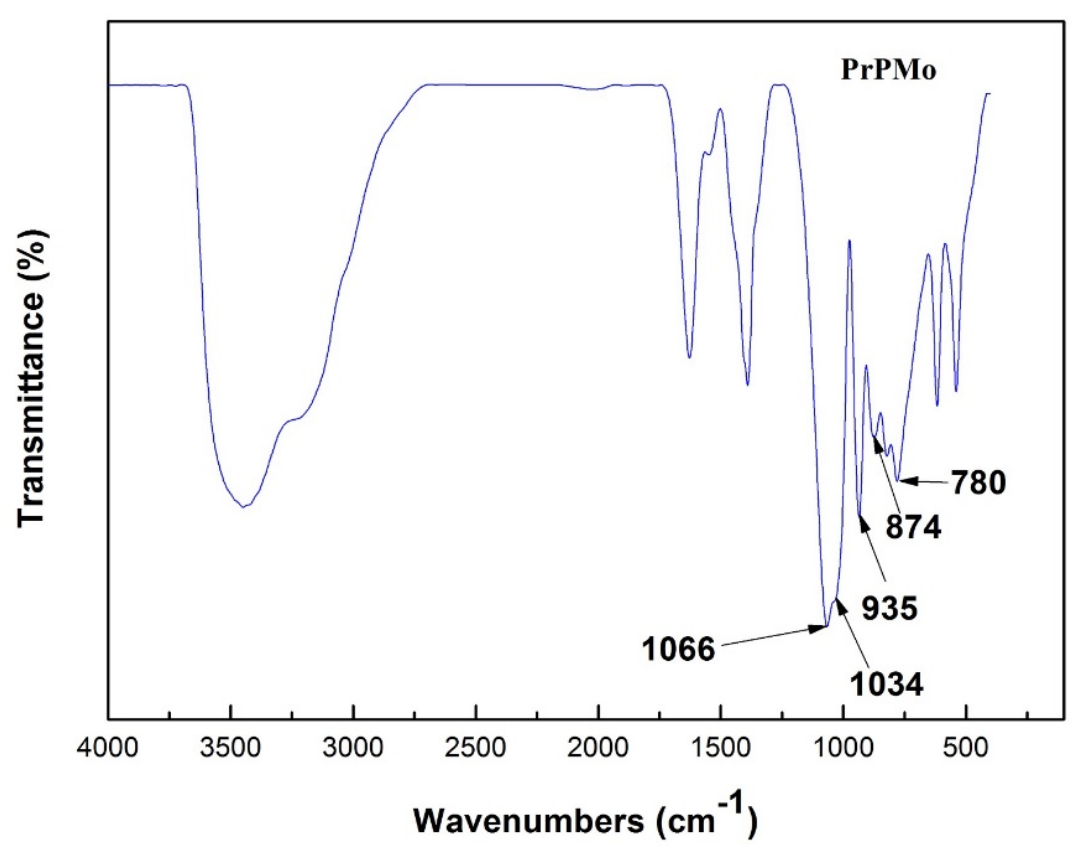

Fig. 1. FT-IR spectrum of $\mathrm{K}_{17}\left[\operatorname{Pr}\left(\mathrm{P}_{2} \mathrm{Mo}_{17} \mathrm{O}_{61}\right)_{2}\right]$. 


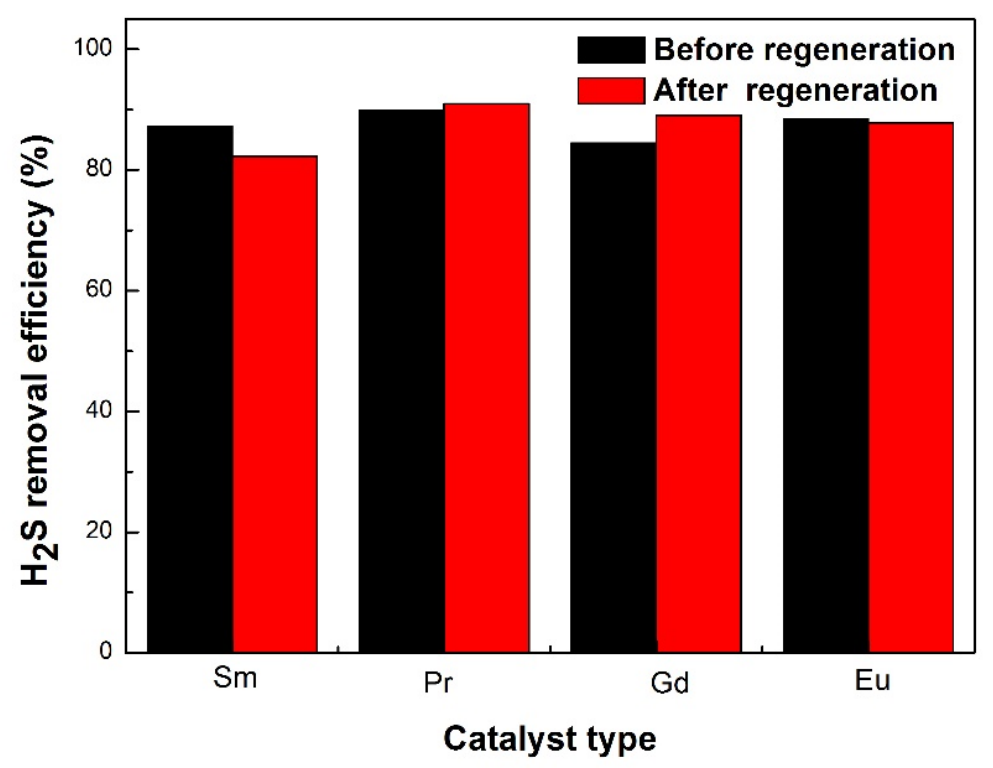

Fig. 2. Effect of lanthanide (III) species on $\mathrm{H}_{2} \mathrm{~S}$ removal.

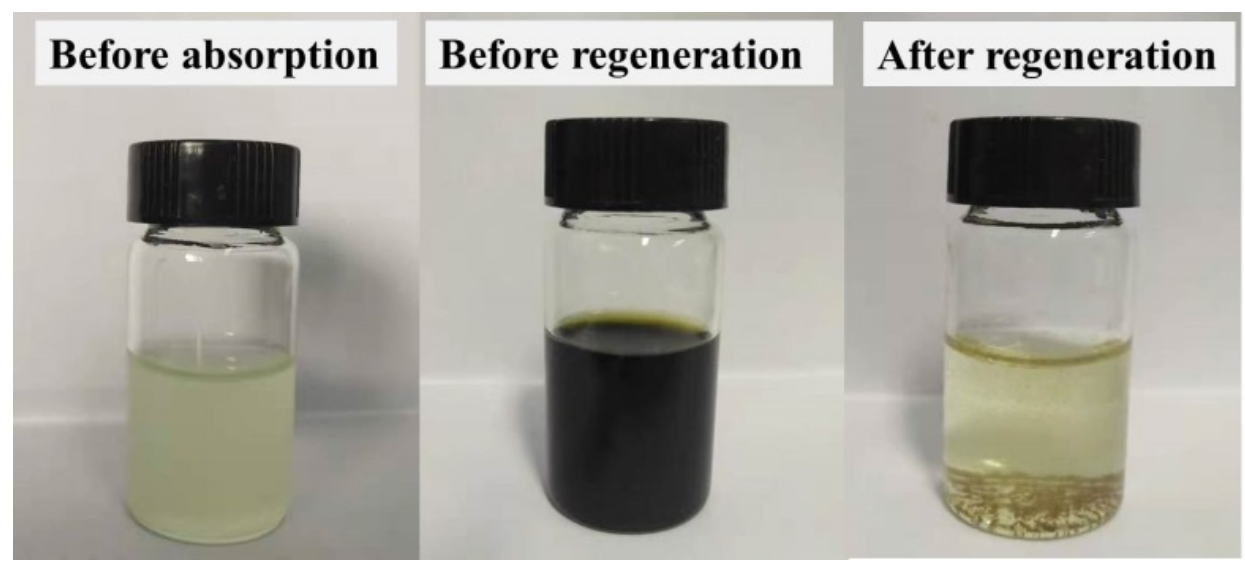

Fig. 3. $\mathrm{K}_{17}\left[\mathrm{Pr}\left(\mathrm{P}_{2} \mathrm{Mo}_{17} \mathrm{O}_{61}\right)_{2}\right]$ color changes before absorption, before regeneration, and after regeneration.

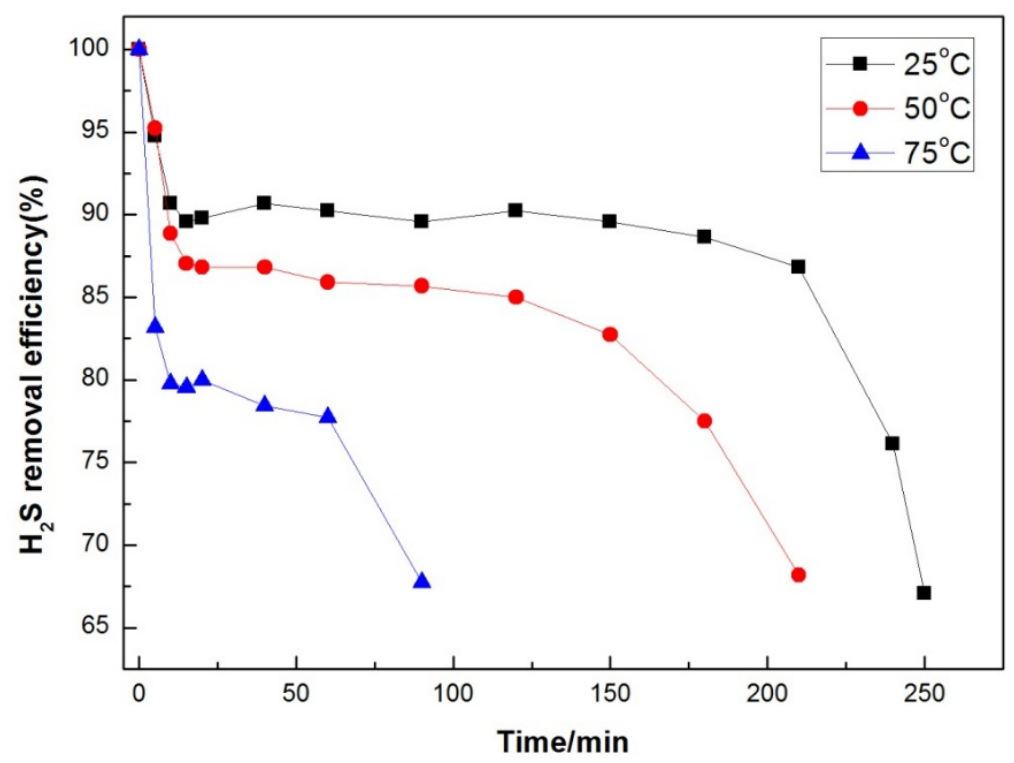

Fig. 4. Effect of temperature on $\mathrm{H}_{2} \mathrm{~S}$ removal. 


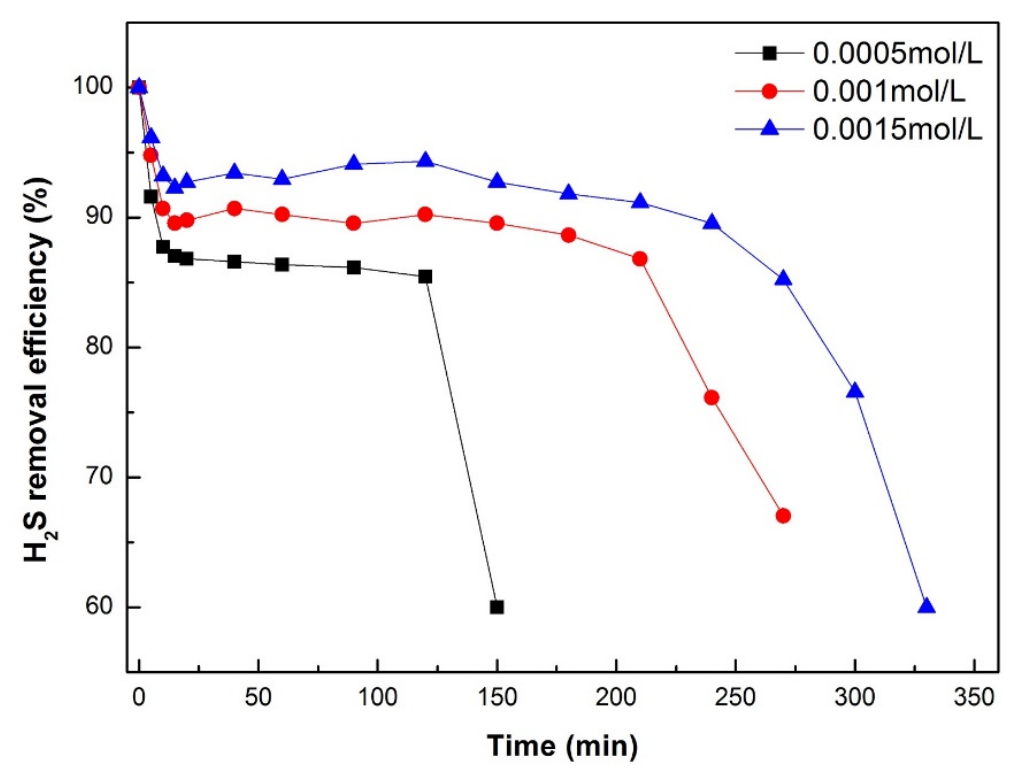

Fig. 5. Effect of PrPMo concentration on $\mathrm{H}_{2} \mathrm{~S}$ removal.

PrPMo during the reaction. Thus, higher PrPMo concentration led to higher $\mathrm{H}_{2} \mathrm{~S}$ removal efficiency. Therefore, the subsequent experiments were performed with $0.0015 \mathrm{~mol} \mathrm{~L}^{-1}$ of PrPMo.

\section{Effect of $\mathrm{H}_{2} \mathrm{~S}$ Concentration on $\mathrm{H}_{2} \mathrm{~S}$ Removal}

Concentration of $\mathrm{H}_{2} \mathrm{~S}$ is also an important factor affecting the $\mathrm{H}_{2} \mathrm{~S}$ removal efficiency of PrPMo. The effect of different concentrations of $\mathrm{H}_{2} \mathrm{~S}$ on the desulfurization performance of PrPMo solution at $25^{\circ} \mathrm{C}$ was studied (Fig. 6). The results revealed that the $\mathrm{H}_{2} \mathrm{~S}$ removal efficiency of PrPMo could remain over $89 \%$ within 300 min under different $\mathrm{H}_{2} \mathrm{~S}$ concentrations. The study showed that at lower $\mathrm{H}_{2} \mathrm{~S}$ concentration, the $\mathrm{H}_{2} \mathrm{~S}$ removal efficiency maintained above $90 \%$ for a longer time. The reason is that PrPMo was sufficient for the reaction at the early stage, but the PrPMo concentration decreased gradually, leading to the low concentration at the later stage. Thus, these results suggested that lower $\mathrm{H}_{2} \mathrm{~S}$ concentration was beneficial for its removal by the PrPMo solution. Considering the actual situation, the subsequent experiments were carried out with $\mathrm{H}_{2} \mathrm{~S}$ concentration of $2200 \mathrm{mg} \mathrm{m}^{-3}$.

\section{Effect of pH on $\mathrm{H}_{2} \mathrm{~S}$ Removal}

$\mathrm{pH}$ plays an important role in the $\mathrm{H}_{2} \mathrm{~S}$ removal efficiency of the absorbent (Zheng et al., 2018). We studied this factor with the $2200 \mathrm{mg} \mathrm{m}^{-3}$ of $\mathrm{H}_{2} \mathrm{~S}$ (Fig. 7). The results showed that $\mathrm{H}_{2} \mathrm{~S}$ removal efficiency increased significantly with the $\mathrm{pH}$ increase from 1 to 5 , but it slightly decreased with the $\mathrm{pH}$ increase from 5 to 9 . The best removal efficiency $(92 \%$ within $250 \mathrm{~min}$ ) has been achieved at $\mathrm{pH} 5$. These results indicated that basic medium (higher $\mathrm{pH}$ value) may destroy the structure of the heteropoly acid, while the heteropoly acid in acidic medium could maintain the stable Dawson structure.

\section{Effect of pH Buffer Solution on $\mathrm{H}_{2} \mathrm{~S}$ Removal}

Since the $\mathrm{pH}$ of the solution is an important factor for the performance of the desulfurization agent, it is worthwhile to discuss how to keep the $\mathrm{pH}$ of the solution stable during the desulfurization process. In this experiment, $\mathrm{pH}$ buffer solution was used to maintain the $\mathrm{pH}$ balance of the solution during the entire reaction. The experiment was carried out with the $\mathrm{H}_{2} \mathrm{~S}$ concentration of $2200 \mathrm{mg} \mathrm{m}^{-3}$. Shown in Fig. 8 are the experimental results. The $\mathrm{H}_{2} \mathrm{~S}$ removal efficiency was improved (achieved $>90 \%$ ) at the $\mathrm{pH}$ range of 2.3 to 6.8 (acidic medium), while the removal efficiency decreased at the $\mathrm{pH}$ range of 6.8 to 12 (basic medium). High desulfurization efficiency can be ascribed mainly to the alkalinity effect. These results indicated that the redox potential and the alkalinity effect of the solution work jointly, with the former being predominant at $\mathrm{pH}$ range below 6.8 . This conforms to the rationale that heteropoly compound has better redox performance at low to medium $\mathrm{pH}$ value. Compared with the direct adjustment of $\mathrm{pH}$ with $\mathrm{HCl}$ and $\mathrm{NaOH}$, the $\mathrm{H}_{2} \mathrm{~S}$ removal efficiency using the $\mathrm{pH}$ buffer solution was significantly improved. The descriptive results of the $\mathrm{pH}$ changes of the solutions before and after absorptionare given in Table 1.

Therefore, under the optimal conditions $\left(25^{\circ} \mathrm{C}\right.$, the 0.0015 mol L ${ }^{-1}$ concentration of PrPMo, the $\mathrm{H}_{2} \mathrm{~S}$ concentration of $2200 \mathrm{mg} \mathrm{m}^{-3}$ and $\mathrm{pH}=6.8$ ), the PrPMo solution had the best desulfurization performance. As shown in Fig. 8, the $\mathrm{H}_{2} \mathrm{~S}$ removal efficiency kept $90 \%$ within $400 \mathrm{~min}$, and then decreased slowly. However, the $\mathrm{pH}$ buffer agent reduced the concentration of $\mathrm{H}^{+}$in the solution, leading to a decrease in the rate of electrochemical regeneration. Therefore, this problem is still worth further investigation.

\section{Desulfurization Mechanism and Desulfurization Products}

FT-IR spectra of PrPMo before and after desulfurization and regeneration are shown in Fig. 9. The presence of four 


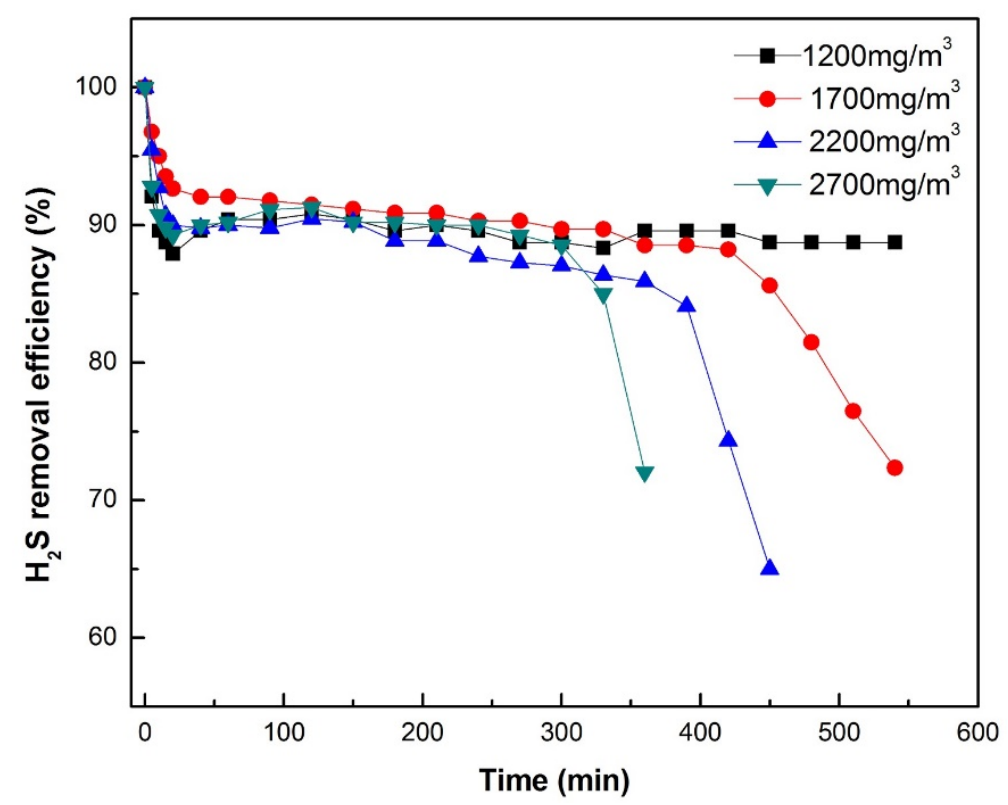

Fig. 6. Effect of $\mathrm{H}_{2} \mathrm{~S}$ concentration on $\mathrm{H}_{2} \mathrm{~S}$ removal.

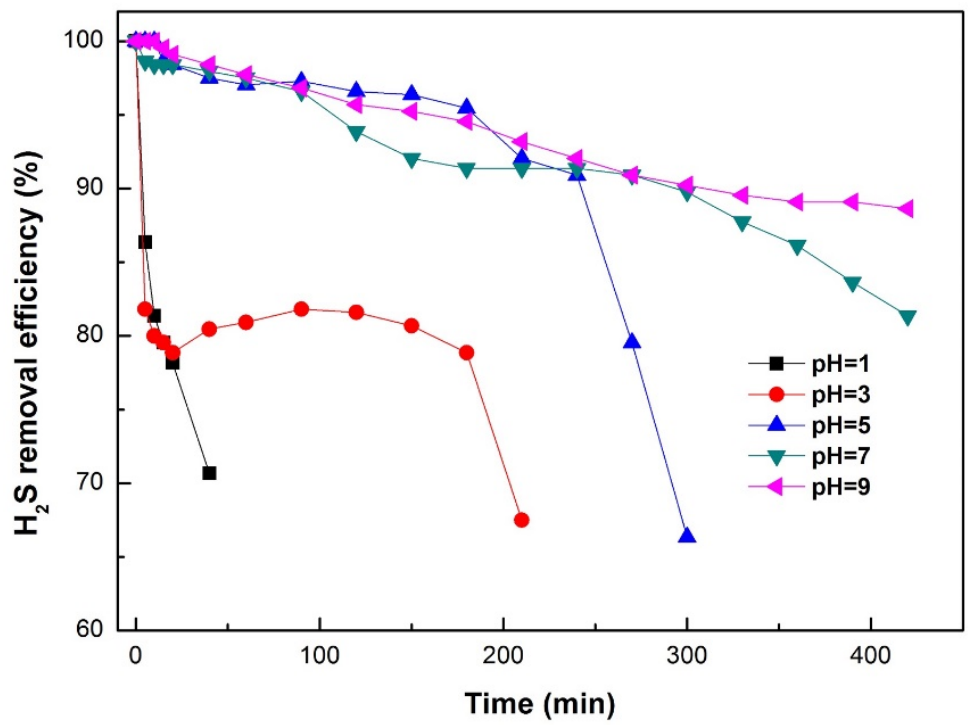

Fig. 7. Effect of $\mathrm{pH}$ on $\mathrm{H}_{2} \mathrm{~S}$ removal.

characteristics peaks of the heteropoly acid anion after absorption and regeneration, indicating that the compound had stable Dawson structure.

The solid powder obtained by evaporating the desulfurizing agents before and after absorption and regeneration was used for XPS analysis. Fig. 10 shows the XPS spectrum of the Mo $3 \mathrm{~d}_{5 / 2}$ orbital on the surface of the PrPMo compound before and after regeneration. Before absorption, the binding energy of Mo $3 \mathrm{~d}_{5 / 2}$ was $233.09 \mathrm{eV}$, indicating that the valency of Mo atom in the compound was +VI. While after absorption, the Mo $3 \mathrm{~d}_{5 / 2}$ spectra of the sample had the two characteristic peaks, i.e., Mo (+IV) at $230.72 \mathrm{eV}$ and Mo (+VI) at $233.27 \mathrm{eV}$. Whereas after electrochemical regeneration, the binding energy returned to $233.42 \mathrm{eV}$, and the valency returned to Mo $(+\mathrm{VI})$. The characterization results showed that $\mathrm{Mo}(+\mathrm{VI})$ in the heteropoly compounds was reduced to Mo (+IV) by $\mathrm{H}_{2} \mathrm{~S}$ during the absorption process, and then was electrochemically regenerated into Mo (+VI) (Muijsers et al., 1995).

The XPS patterns of the S $2 p$ orbitals of the compounds before and after regeneration are shown in Fig. 11. The $\mathrm{S}$ orbital of the heteropoly compound before regeneration existed in various valence states. The characteristic peak with the binding energy of $162.03 \mathrm{eV}$ indicated that $\mathrm{H}_{2} \mathrm{~S}$ gas was absorbed, and the valence of sulfur element was -II. While, the characteristic peak with the binding energy of $163.45 \mathrm{eV}$ belonged to $\mathrm{S}(0)$ orbital. Whereas, the characteristic peak at $168.94 \mathrm{eV}$ proved the presence of $\mathrm{SO}_{4}{ }^{2-}$. After electrochemical regeneration, the area of characteristic peak belonging to $\mathrm{SO}_{4}{ }^{2-}$ was significantly increased. A white 


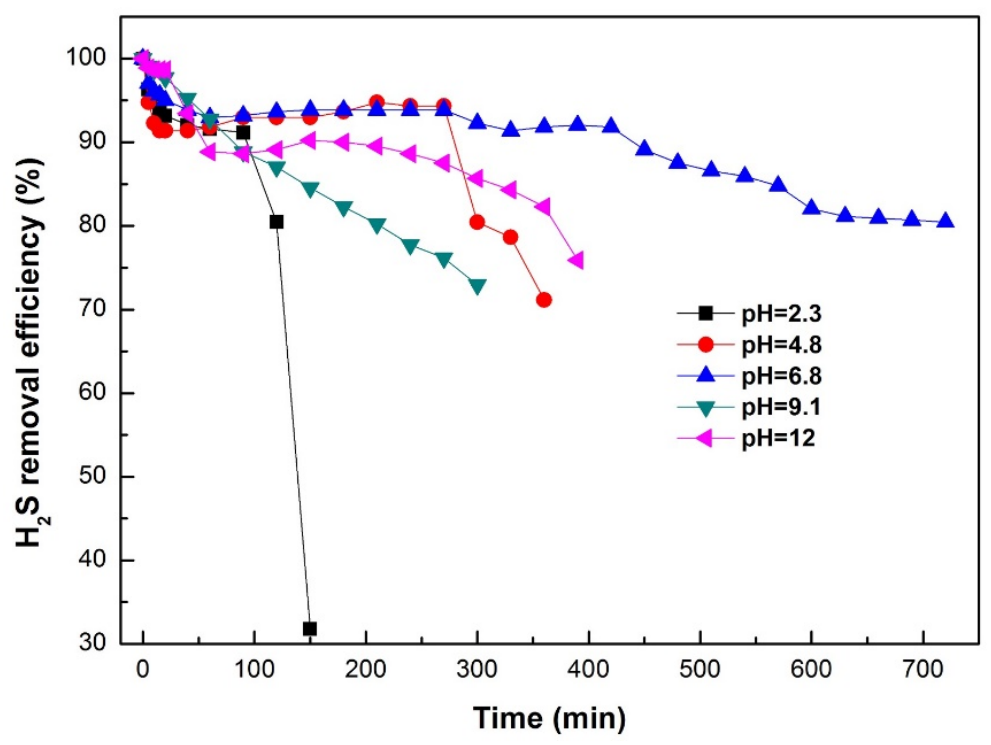

Fig. 8. Effect of $\mathrm{pH}$ buffer solution on $\mathrm{H}_{2} \mathrm{~S}$ removal.

Table 1. The $\mathrm{pH}$ changes of the two solutions before and after absorption.

\begin{tabular}{llll}
\hline & Before absorption & After absorption & Difference \\
\hline Adjust the $\mathrm{pH}$ of the solution with $\mathrm{HCl}$ and & 1 & 1.36 & +0.36 \\
$\mathrm{NaOH}$ & 3 & 3.55 & +0.55 \\
& 5 & 5.34 & +0.34 \\
& 7 & 7.60 & +0.60 \\
Adjust the pH of the solution with a pH buffer & 9 & 7.40 & -1.60 \\
solution & 2.3 & 2.43 & +0.13 \\
& 4.8 & 4.90 & +0.10 \\
& 6.8 & 6.94 & +0.14 \\
& 9.1 & 8.96 & -0.04 \\
\hline
\end{tabular}

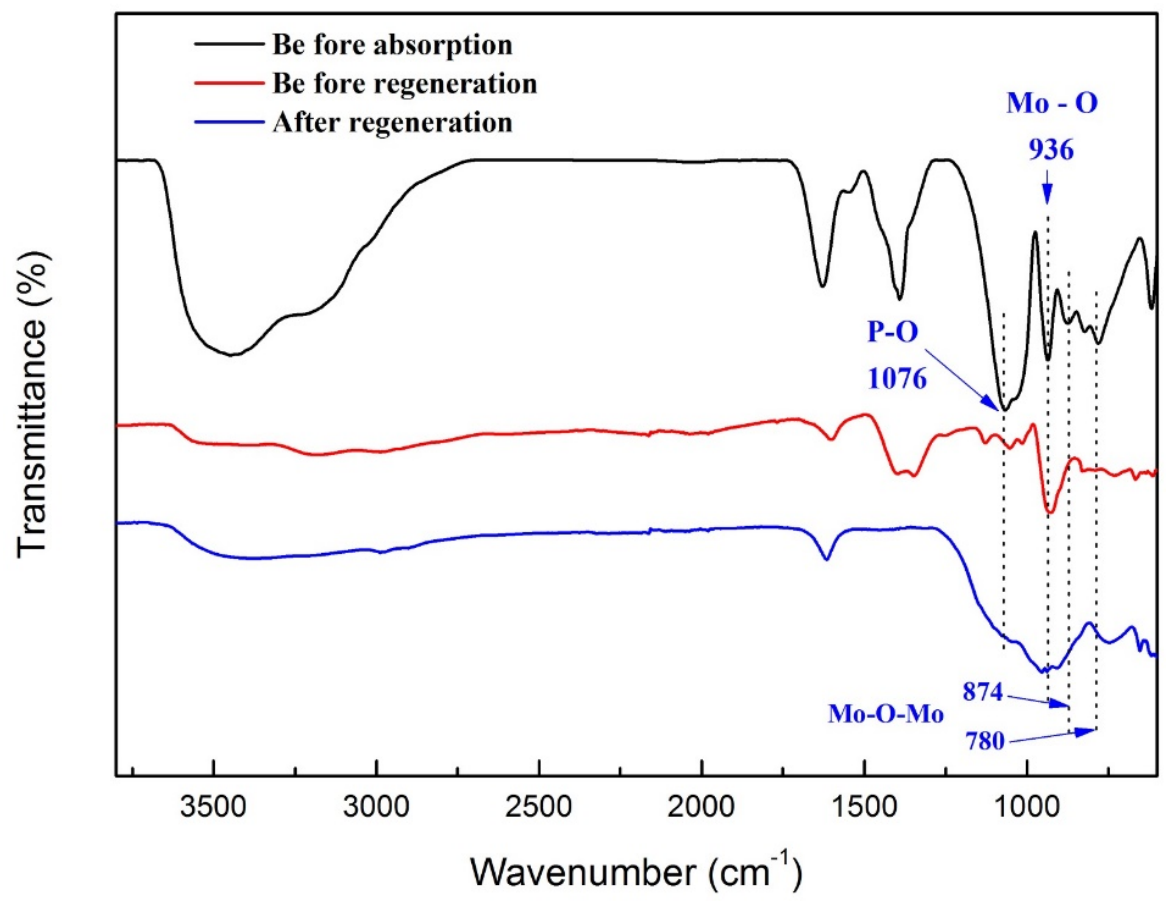

Fig. 9. FT-IR spectra of PrPMo after and before study. 


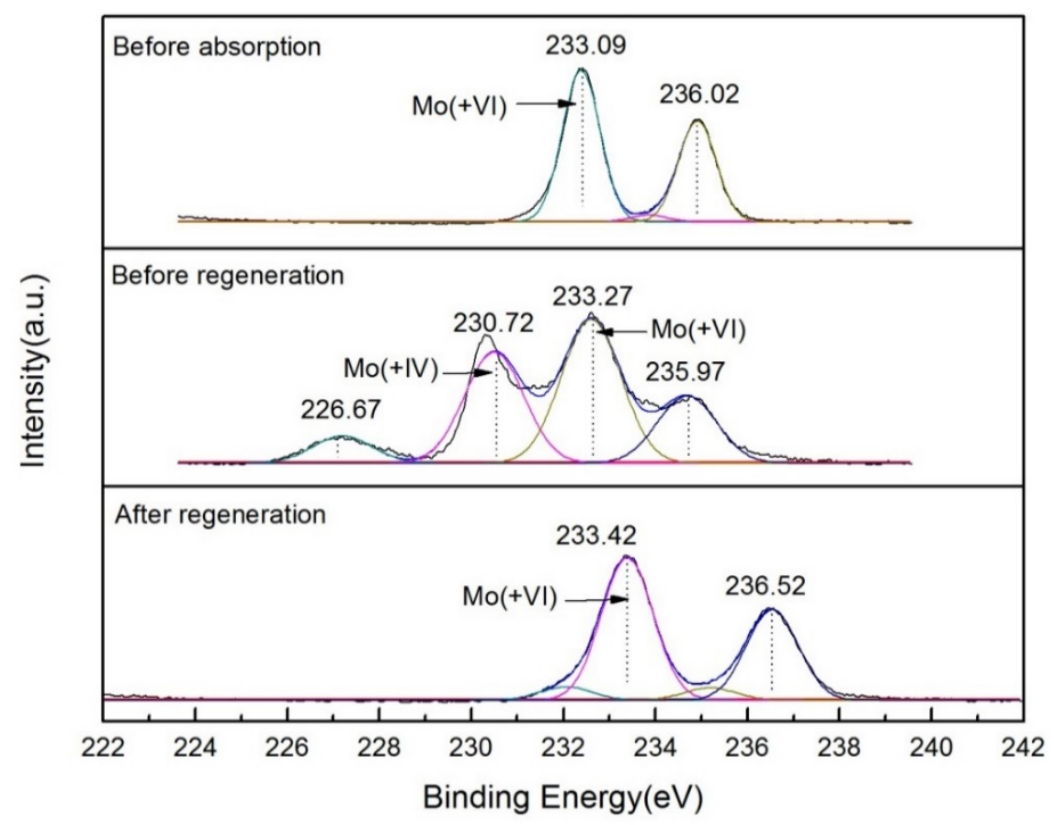

Fig. 10. The XPS spectra of Mo 3d of samples before absorption as well as before and after regeneration.

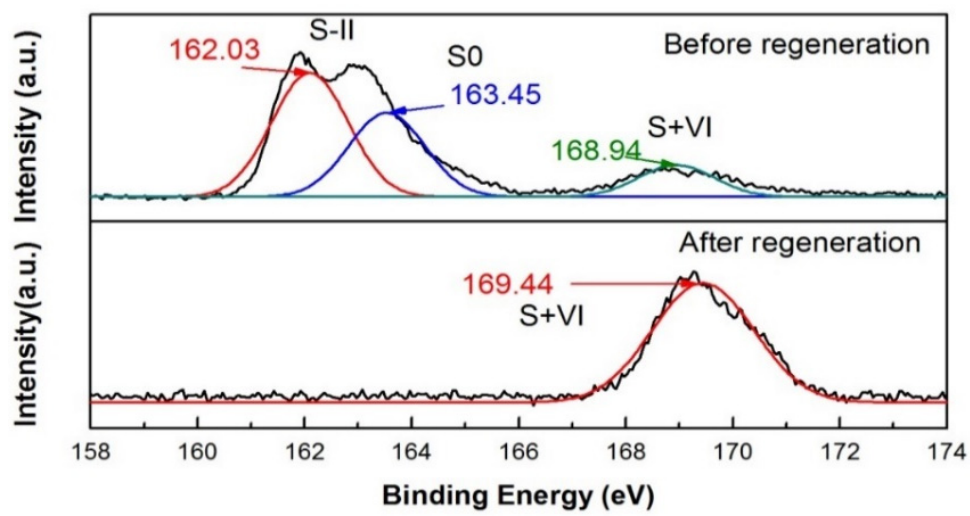

Fig. 11. The XPS spectra of $S 2 p$ of samples before and after regeneration.

precipitate can be found by adding $\mathrm{BaCl}_{2}$ solution into the desulfurization reagent after regeneration. The above results proved that the desulfurization product was $\mathrm{SO}_{4}{ }^{2-}$ (Baker $e t$ al., 1999).

The XPS patterns of the Pr $3 \mathrm{~d}$ orbital of the compound before and after absorption and after electrochemical regeneration are shown in Fig. 12. XPS spectra showed the three characteristic peaks for the $\operatorname{Pr} 3 \mathrm{~d}_{5 / 2}$ orbital with the absorption energies of 933.37 eV and 954.27 eV (before H2S absorption), indicating that Pr in the PrPMo was +III state. Whereas an absorption peak with a binding energy of $975.77 \mathrm{eV}$ indicated that $\mathrm{Pr}$ in the PrPMo was +IV state (Lutkehoff et al., 1995; PoggioFraccari et al., 2018). After $\mathrm{H}_{2} \mathrm{~S}$ absorption, the intensity of characteristic peak belonging to $\operatorname{Pr}$ (+III) was significantly reduced. But it increased again after electrochemical regeneration. In conclusion, XPS study proved that rare earth element $(\mathrm{Pr})$ participated in the desulfurization reaction and played a key role in the absorption and conversion of $\mathrm{H}_{2} \mathrm{~S}$.

Thus, the desulfurization mechanism of PrPMo can be illustrated as follows: during the absorption process, $\mathrm{H}_{2} \mathrm{~S}$ was oxidized into $\mathrm{S}$ and $\mathrm{SO}_{4}{ }^{2-}$ through the redox of PrPMo. At the same time, the Mo (+VI) in PrPMo was reduced to Mo (+IV). In the electrochemical regeneration process, $\mathrm{S}$ in the reaction system was converted to $\mathrm{SO}_{4}{ }^{2-}$. Furthermore, $\mathrm{Pr}$ was reduced from $\operatorname{Pr}(+\mathrm{IV})$ to $\operatorname{Pr}(+\mathrm{III})$ after regeneration. Mo 3d of PrPMo after regeneration exhibited a similar XPS spectrum with that before absorption, suggesting that PrPMo was successfully regenerated since Mo (+IV) was oxidized back to Mo $(+\mathrm{VI})$ after electrochemical regeneration. Based on the above analysis, we inferred that PrPMo played a redox role in desulfurization.

In Table 2, we compared the PrPMo with the previous desulfurization reagents. Liu et al. (2017c) and Lütkehoff et al. (1995) found that the desulfurization efficiency of the pure phosphotungstic acid $\left(\mathrm{H}_{3} \mathrm{PW}_{12} \mathrm{O}_{40}\right)$ and phosphomolybdic acid $\left(\mathrm{H}_{3} \mathrm{PMo}_{12} \mathrm{O}_{40}\right)$ was $20 \%$ and $80 \%$, respectively. Ma et al. (2014) and Wang et al. (2003) used V and W to substitute the part elements of phosphomolybdic acid to form 


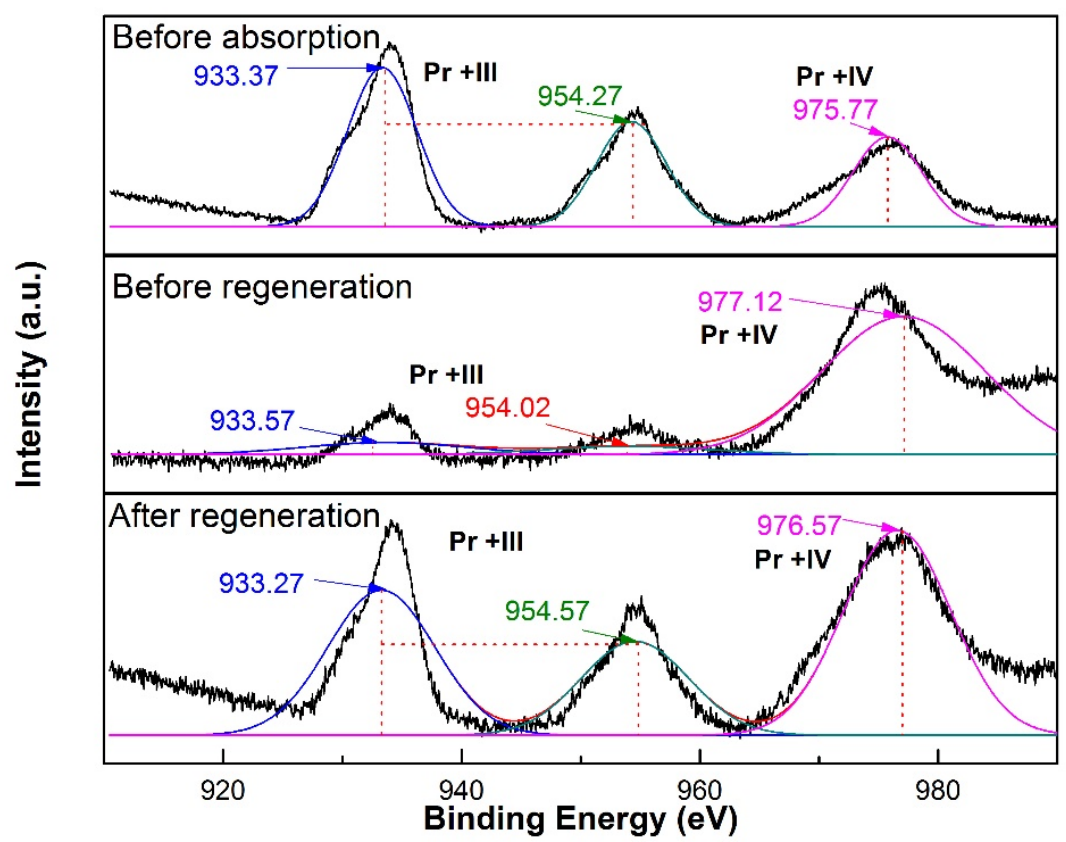

Fig. 12. The XPS spectra of $\operatorname{Pr} 3 \mathrm{~d}$ of samples before absorption as well as before and after regeneration.

Table 2. A comprehensive study of the rare earth doped PrPMo compound for the removal of $\mathrm{H}_{2} \mathrm{~S}$ gas.

\begin{tabular}{llll}
\hline S. No. & Name of compound & Efficiency of $\mathrm{H}_{2} \mathrm{~S}$ removal & References \\
\hline 1. & PrPMo & $90 \%$ & Fig. 2 \\
2. & $\left(\mathrm{NH}_{4}\right)_{11}\left[\mathrm{Sm}_{2}\left(\mathrm{PMo}_{11} \mathrm{O}_{39}\right)_{2}\right.$ & $80 \%$ & Liu et al. $(2017 \mathrm{c})$ \\
3. & $\mathrm{H}_{3} \mathrm{PW}_{12} \mathrm{O}_{40}$ & $20 \%$ & Liu et al. $(2017 \mathrm{c})$ \\
4. & $\mathrm{H}_{3} \mathrm{PMo}_{12} \mathrm{O}_{40}$ & $80 \%$ & Lütkehoff et al. $(1995)$ \\
5 & $\mathrm{H}_{7}\left[\mathrm{P}_{2} \mathrm{MO}_{17} \mathrm{VO}_{62}\right] \cdot 39 \mathrm{H}_{2} \mathrm{O}$ & $85 \%$ & Ma et al. $(2014)$ \\
6. & $\mathrm{H}_{3} \mathrm{PW}_{10} \mathrm{Mo}_{2} \mathrm{O}_{40}$ & $85 \%$ & Wang et al. $(2003)$ \\
\hline
\end{tabular}

$\mathrm{H}_{7}\left[\mathrm{P}_{2} \mathrm{Mo}_{17} \mathrm{VO}_{62}\right] \cdot 39 \mathrm{H}_{2} \mathrm{O}$ and $\mathrm{H}_{3} \mathrm{PW}_{10} \mathrm{Mo}_{2} \mathrm{O}_{40}$, respectively, to remove $\mathrm{H}_{2} \mathrm{~S}$. The results showed that the desulfurization efficiency of them was only $85 \%$ (Wang et al., 2003; Ma et al., 2014). Thus, we found herein that the PrPMo compounds had better performance for the removal of $\mathrm{H}_{2} \mathrm{~S}$

\section{CONCLUSION}

We investigated the desulfurization performance of a series of rare earth ion doped heteropolymolybdates under different reaction conditions. The results can be summarized as follows:

(1) FT-IR spectrum proved the successful synthesis of LnPMo $\left(\mathrm{Ln}=\mathrm{Pr}^{3+}, \mathrm{Gd}^{3+}, \mathrm{Sm}^{3+}\right.$, and $\left.\mathrm{Eu}^{3+}\right)$.

(2) PrPMo solution had ideal desulfurization capability at room temperature. The absorbent could achieve a $\mathrm{H}_{2} \mathrm{~S}$ removal efficiency of $90 \%$ within $400 \mathrm{~min}$. At higher concentration of the PrPMo, $\mathrm{H}_{2} \mathrm{~S}$ removal efficiency became higher accordingly.

(3) Low $\mathrm{H}_{2} \mathrm{~S}$ concentration was suitable for the desulfurization reaction. PrPMo had the highest desulfurization efficiency at $\mathrm{pH} 6.8$.

(4) The final product of desulfurization was $\mathrm{SO}_{4}{ }^{2-}$. PrPMo played a role of redox in desulfurization and could convert $\mathrm{H}_{2} \mathrm{~S}$ into sulfur resources.

\section{ACKNOWLEDGEMENTS}

This work was supported by the Scientific Innovation Program of Shenzhen City, China, under basic research program (JCYJ20170818102915033), the National Natural Science Foundation of China (Nos: 21276144, 21511130021), and the Key Research and Development Program of Shandong Province, China (2017GSF217006).

\section{REFERENCES}

Baker, M., Gilmore, R., Lenardi, C. and Gissler, W. (1999). XPS investigation of preferential sputtering of $\mathrm{S}$ from $\mathrm{MoS}_{2}$ and determination of MoSx stoichiometry from Mo and S peak positions. Appl. Surf. Sci. 150: 255-262.

Bamdad, H., Hawboldt, K. and MacQuarrie, S. (2018). A review on common adsorbents for acid gases removal: Focus on biochar, Renewable Sustainable Energy Rev. 81: 1705-1720.

Beidari, M., Lin, S.J. and Lewis, C. (2017). Multiplier effects of energy consumption and $\mathrm{CO}_{2}$ emissions by input-output analysis in South Africa. Aerosol Air Qual. Res. 17: 1666-1678.

Chandran, D., Khalid, M. and Walvekar, R. (2018). Deep eutectic solvents for extraction-desulphurization: A 
review. J. Mol. Liq. 275: 312-322.

Chen, L., Zhou, J., Zheng, X., Wu, J., Wu, X., Gao, X. and Cen, K. (2017). Effects of carbon dioxide addition on the soot particle sizes in an ethylene/air flame. Aerosol Air Qual. Res. 17: 2522-2532.

Cheng, B. and Wang-Li, L. (2019). Responses of secondary inorganic $\mathrm{PM}_{2.5}$ to precursor gases in an ammonia abundant area in North Carolina. Aerosol Air Qual. Res. 19: 1126-1138.

Cheng, S.W., Li, Y.H., Yuan, C.S., Tsai, P.Y., Shen, H.Z., and Hung, C.H. (2018). An innovative advanced oxidation technology for effective decomposition of formaldehyde by combining iron modified nano- $\mathrm{TiO}_{2}$ $\left(\mathrm{Fe} / \mathrm{TiO}_{2}\right)$ photocatalytic degradation with ozone oxidation. Aerosol Air Qual. Res. 18: 3220-3233.

Habeeb, O.A., Kanthasamy, R. and Ali, G.A.M. (2018). Hydrogen sulfide emission sources, regulations, and removal techniques: A review. Rev. Chem. Eng. 34: 837854.

Haraguchi, N., Okaue, Y., Isobe, T. and Matsuda, Y. (1994). Stabilization of tetravalent cerium upon coordination of unsaturated heteropolytungstate anions. Inorg. Chem. 33: 1015-1020.

Huang, K., Zhang, X., Zhou, L., Tao, D. and Fan, J. (2017). Highly efficient and selective absorption of $\mathrm{H}_{2} \mathrm{~S}$ in phenolic ionic liquids: A cooperative result of anionic strong basicity and cationic hydrogenbond donation. Chem. Eng. Sci. 173: 253-263.

Huang, Y. and Wang, R. (2019a). Highly selective separation of $\mathrm{H}_{2} \mathrm{~S}$ and $\mathrm{CO}_{2}$ using a $\mathrm{H}_{2} \mathrm{~S}$-imprinted polymers loaded on a polyoxometalate@ Zr-based metalorganic framework with a core-shell structure at ambient temperature. J. Mater. Chem. A 7: 12105-12114.

Huang, Y., Su, W., Wang, R. and Zhao, T. (2019b). Removal of typical industrial gaseous pollutants: From carbon, zeolite, and metal-organic frameworks to molecularly imprinted adsorbents. Aerosol Air Qual. Res. 19: 2130-2150.

Jiang, J., Chan, A. and Ali, S. (2016). Hydrogen sulfidemechanisms of toxicity and development of an antidote. Sci. Rep. 6: 20831-20831.

Jiang, Y., Bao, C., Liu, S., Liang, G., Lu, M., Lai, C. and Ma, S. (2018). Enhanced activity of Nb-modified $\mathrm{CeO}_{2} / \mathrm{TiO}_{2}$ catalyst for the selective catalytic reduction of $\mathrm{NO}$ with $\mathrm{NH}_{3}$. Aerosol Air Qual. Res. 18: 2121-2130.

Ko, T.H. and Hsueh, H.T. (2012). Removal of hydrogen sulfide by iron-rich soil: Application of the deactivation kinetic model for fitting breakthrough curve. Aerosol Air Qual. Res. 12: 1355-1361.

Ko, J.H., Xu, Q. and Jang, Y.C. (2015). Emissions and control of hydrogen sulfide at landfills: A review. Crit. Rev. Environ. Sci. Technol. 45: 2043-2083.

Kozhevnikov, I.V. and Matveev, K.I. (1982). Heteropolyacids in catalysis. Russ. Chem. Rev. 51: 10751088.

Lee, S. and Kim, D. (2019). Enhanced adsorptive removal of hydrogen sulfide from gas stream with zinciron hydroxide at room temperature. Chem. Eng. J. 363: 4348 .
Li, G., Ding, Y., Wang, J., Wang, X. and Suo, J. (2007). New progress of Keggin and Wells-Dawson type polyoxometalates catalyze acid and oxidative reactions. $J$. Mol. Catal. A: Chem. 262: 67-76.

Liu, S., Yang, H., Zhang, Z., Chen, J., Chen, C., Guo, T., and Jia, W. (2018). Emission characteristics of fine particles from Wet Flue Gas Desulfurization system using a cascade of double towers. Aerosol Air Qual. Res. 18: 1901-1909.

Liu, S., Yu, X., Lin, G., Qu, R., Zheng, C. and Gao, X. (2019). Insights into the effect of adsorption-desorption cycles on $\mathrm{SO}_{2}$ removal over an activated carbon. Aerosol Air Qual. Res. 19: 411-421.

Liu, X. and Wang, R. (2017a). An innovative approach to oxidative removal of hydrogen sulfide using the solution of peroxo heteropolyacid. Aerosol Air Qual. Res. 17: 1341-1346.

Liu, X. and Wang, R. (2017b). $\mathrm{H}_{2} \mathrm{~S}$ removal by peroxo heteropoly compound/ionic liquid solution. Fuel Process. Technol. 160: 78-85.

Liu, X., Li, J. and Wang, R. (2017c). Desulfurization and regeneration performance of heteropoly compound/ionic liquid solutions at high temperature. Chem. Eng. J. 316: 171-178.

Liu, Y., Lu, S., Wang, H., Yang, C., Su, X. and Xiang, Y. (2017d). An aqueous redox flow battery with a tungstencobalt heteropolyacid as the electrolyte for both the anode and cathode. Adv. Sci. News 07: 1601224-1601224.

Luo, Q.H., Howell, R.C., Dankova, M., Bartis, J. and Williams, C.W. (2001). Coordination of rare-earth elements in complexes with monovacant Wells-Dawson polyoxoanions. Inorg. Chem. 40: 1894-1901.

Lütkehoff, S., Neumann, M. and Ślebarski, A. (1995). 3d and $4 \mathrm{~d} \mathrm{x}$-ray-photoelectron spectra of Pr under gradual oxidation. Phys. Rev. B 52: 19-19.

Ma, Y. and Wang, R. (2014). $\mathrm{H}_{2} \mathrm{~S}$ absorption capacity and regeneration performance of amine Febased ionic liquid. Chem. J. Chin. Univ. 35: 760-765. (in Chinese)

Muijsers, J., Weber, T., Vanhardeveld, R. and Zandbergen, H.W. J. (1995). Niemantsverdriet, Sulfidation study of molybdenum oxide using $\mathrm{MoO}_{3} / \mathrm{SiO}_{2} / \mathrm{Si}(100)$ model catalysts and MoIV 3-sulfur cluster compounds. J. Catal. 157: 698-705.

Niu, J., Zhao, J., Guo, D. and Wang, J. (2004). Preparation, electrochemistry and crystal structure of a derivative of 18-tungstophosphate with Dawson structure: $\mathrm{K}_{16} \mathrm{H}[\mathrm{Yb}(\mathrm{a}-$ 2- $\left.\left.\mathrm{P}_{2} \mathrm{~W}_{17} \mathrm{O}_{61}\right)_{2}\right] \cdot 44 \mathrm{H}_{2}$ O. J. Mol. Struct. 692: 223-229.

Ou, G., Yang, H. and Fang, Y. (2001). Progress in research on supported heteropolyacid catalysts. Chem. Ind. Eng. Prog. 8: 005-005. (in Chinese)

Ozekmekci, M., Salkic, G. and Fellah, M.F. (2015). Use of zeolites for the removal of $\mathrm{H}_{2} \mathrm{~S}$ : A mini-review. Fuel Process. Technol. 139: 49-60.

Pan, S.Y., Chiang, A., Chang, E.E., Lin, Y.P., Kim, H. and Chiang, P.C. (2015). An innovative approach to integrated carbon mineralization and waste utilization: A review. Aerosol Air Qual. Res. 15: 1072-1091.

Peacock, R.D. and Weakley, T.J.R. (1971a). Heteropolytungstate complexes of the lanthanide 
elements. Part I. Preparation and reactions. J. Chem. Soc. A 12: 1863-1839.

Peacock, R.D. and Weakley, T.J.R. (1971b). Heteropolytungstate complexes of the lanthanide elements. Part II. Electronic spectra: A metal-ligand charge-transfer transition of cerium(III). J. Chem. Soc. A 12: 1937-1940.

Poggio-Fraccari, E., Baronetti, G. and Mariño, F. (2018). $\mathrm{Pr}^{3+}$ surface fraction in CePr mixed oxides determined by XPS analysis. J. Electron Spectrosc. Relat. Phenom. 222: $1-4$.

Tian, H., Wu, J. and Zhang, W. (2017). High performance of $\mathrm{Fe}$ nanoparticles/carbon aerogel sorbents for $\mathrm{H}_{2} \mathrm{~S}$ removal. Chem. Eng. J. 313:1051-1060.

Timofeeva, M.N. (2003). Acid catalysis by heteropoly acids. Appl. Catal., A 256: 9-35.

Wang, D., Yan, L. and Wang X. (2012). Progress in Research on heteropoly acid catalysts. J. Mol. Catal. 26: 366-375. (in Chinese)

Wang, L., Huang, B. and Xie, Z. (2006). Assembly and electrochemical behavior of polyoxometalate $\mathrm{K}_{17}\left[\mathrm{Ce}\left(\mathrm{P}_{2} \mathrm{Mo}_{17} \mathrm{O}_{61}\right)_{2}\right]$ multilayer modified electrode. Chem. Res. Chin. Univ. 27: 543-545. (in Chinese)

Wang, R. and Gao, H. (2003). Heteropoly acid as new liquid redox absorbent for low sulfur containing gas sweetening. Macro Rev. 16: 141-145.

Wang, Y., Wang, Z. and Pan, Z. (2019). Removal of gaseous hydrogen sulfide using fenton reagent in a spraying reactor. Fuel 239: 70-75.

Widiana, D.R., Wang, Y.F., You, S.J., Yang, H.H., Wang, L.C., Tsai, J.H. and Chen, H.M. (2019). Air pollution profiles and health risk assessment of ambient volatile organic compounds above a municipal wastewater treatment plant, Taiwan. Aerosol Air Qual. Res. 19: 375382.

Widiana, D.R., You, S.J., Yang, H.H., Tsai, J.H. and Wang, Y.F. (2017). Source apportionment of air pollution and characteristics of volatile organic compounds in a municipal wastewater treatment plant, North Taiwan. Aerosol Air Qual. Res. 17: 2878-2890.

Xie, W., Yu, M. and Wang, R. (2017). $\mathrm{CO}_{2}$ capture behaviors of amine-modified resorcinol-based carbon aerogels adsorbents. Aerosol Air Qual. Res. 17: 27152725.

Yang, D., Chen, G. and Zhang, R. (2006). Estimated public health exposure to $\mathrm{H}_{2} \mathrm{~S}$ emissions from a Sour gas well blowout in Kaixian County, China. Aerosol Air Qual. Res. 6: 430-443.

Yoshida, S., Murakami, H., Sakai, Y. and Nomiya, K. (2008). Syntheses, molecular structures and $\mathrm{pH}$ dependent monomer-dimer equilibria of Dawson $\alpha 2$ monotitanium (IV)-substituted polyoxometalates. Dalton Trans. 1: 4630-4638.

Zhai, L., Song, W., Tong, Z. and Sun, M. (2012). A fuelcell-assisted iron redox process for simultaneous sulfur recovery and electricity production from synthetic sulfide wastewater. J. Hazard. Mater. 243: 350-356.

Zhang, F., Zhang, X., Jiang, G., Li, N., Hao, Z. and Qu S. (2018). $\mathrm{H}_{2} \mathrm{~S}$ selective catalytic oxidation over $\mathrm{Ce}$ substituted $\mathrm{La}_{1-\mathrm{x}} \mathrm{Ce}_{\mathrm{x}} \mathrm{FeO}_{3}$ perovskite oxides catalyst. Chem. Eng. J. 348: 831-839.

Zhang, S., Zhu, X., Zheng, C., Hu, D., Zhang, J. and Gao, $X$. (2017). Study on catalytic soot oxidation over spinel type $\mathrm{ACo}_{2} \mathrm{O}_{4}(\mathrm{~A}=\mathrm{Co}, \mathrm{Ni}, \mathrm{Cu}, \mathrm{Zn})$ catalysts. Aerosol Air Qual. Res. 17: 2317-2327.

Zheng, W., Wu, D., Feng, X., Hu, J., Zheng, F., Wu, Y. and $\mathrm{Hu}$, X. (2018). Low viscous Protic ionic liquids functionalized with multiple Lewis Base for highly efficient capture of $\mathrm{H}_{2}$ S. J. Mol. Liq. 263: 209-217.

Received for review, October 26, 2019 Revised, November 19, 2019 Accepted, November 19, 2019 